\title{
Research on the Pass Problems of the Studio Practice Teaching Mode of the Application-oriented Undergraduate
}

_-Taking the Biding and Contract Management studio of the Application-oriented Undergraduate as an Example

\author{
Ling Yan ${ }^{1, a}$, Yuwei Chen ${ }^{1, b}$ \\ ${ }^{1}$ School of Management, Tianjing University of Technology, Tianjing 300384, China \\ alingyantj@163.com, byuweichen0423@163.com
}

Keywords: Application-oriented Undergraduate; studio; pass problem; Case Teaching; Process Reengineering

\begin{abstract}
The key of running the Studio Practice Teaching Mode of the application-oriented Undergraduate is to set appropriate pass problems. The establishment of problem-oriented teaching methods will effectively link the students' abilities training and the knowledge utilization. However, how the pass problems work in the studio practice teaching mode needs urgent in-depth discussions. Taking the biding and contract management studio of the application-oriented undergraduate as an example, firstly combine the actual case to research the design principles, the design methods and the main question classification of the pass problems; secondly reengineer the process of the pass problems oriented teaching from the aspects of the method of teaching, learning and evaluation. The results show that only the pass problems function as a guide of the studio practice teaching mode in the application-oriented undergraduate, the objective of the studio practice teaching that considers students as the center of class, integrating knowledge through solving problems to gain practical abilities can finally come true.
\end{abstract}

\section{Introduction}

Application - oriented Undergraduate is the product of the higher education, which emphasize the consilience of talent training goal with the needs of the industry and enterprises [1,2]. Many colleges and universities have undertaken the Studio Practice Teaching Mode at the core of cultivating the students' practical abilities, in order to promote students obtaining the practice skills in needs of the industry [3]. The Studio Practice Teaching Mode is the integrated teaching model that takes the study of students as the center and emphasizes the simulation inside school [4], the problems of which is the starting point and the final destination of the teaching design. If teach in the knowledge-oriented way and pay much attention on the theoretical teaching, the studio won't be conducive to the training of the students' practical abilities. Thus, the studio practice teaching gradually build the teaching process based on "project - task - pass problem”[5].

Combining the exploring teaching based on the problem learning with the studio practice teaching can inspire the students' enthusiasm and help students cultivating their sense of innovation[6]. However, the problems is set and presented by the teachers to create certain situations or promote students' thinking and the completion of task[7]. Apparently, the key of the 
problem-oriented studio practice teaching mode is to transform the structured knowledge into the stereoscopic and real problems and tasks[8][9][10],and the pass problems precisely is the link between the competency elements and the knowledge unit.

In view of this, combining the practice part of college engineering management undergraduate specialty, describe and analyze the classification and design principles of the pass problems during the process of studio practice teaching, aimed to give some references for the conduction of studio practice teaching, looking forward to improve teaching effectiveness of the studio practice teaching.

\section{The Correspondence between Pass Problems and Cases in the Studio Practice Teaching}

Taking the cases as the drive, the studio practice teaching demonstrate and simulate future specific work by the form of situational embedding [11]. Therefore, the content design should first focus on designing teaching cases in the studio practice teaching. However, a engineering case has miscellaneous information and teachers cannot participate in the project generally in order to gain first-hand information of the project. And from the perspective of the completion of teaching task, completing the project does not need to present all the information about a particular case. But, the case has always been throughout the project in the studio practice teaching. It is decisive for the structure of case design to know how to transform the collected information to the information required for the students to complete the task and present teaching cases selectively and methodically. Presence of pass problems in the studio practice teaching provide a scientific structure for the case design.

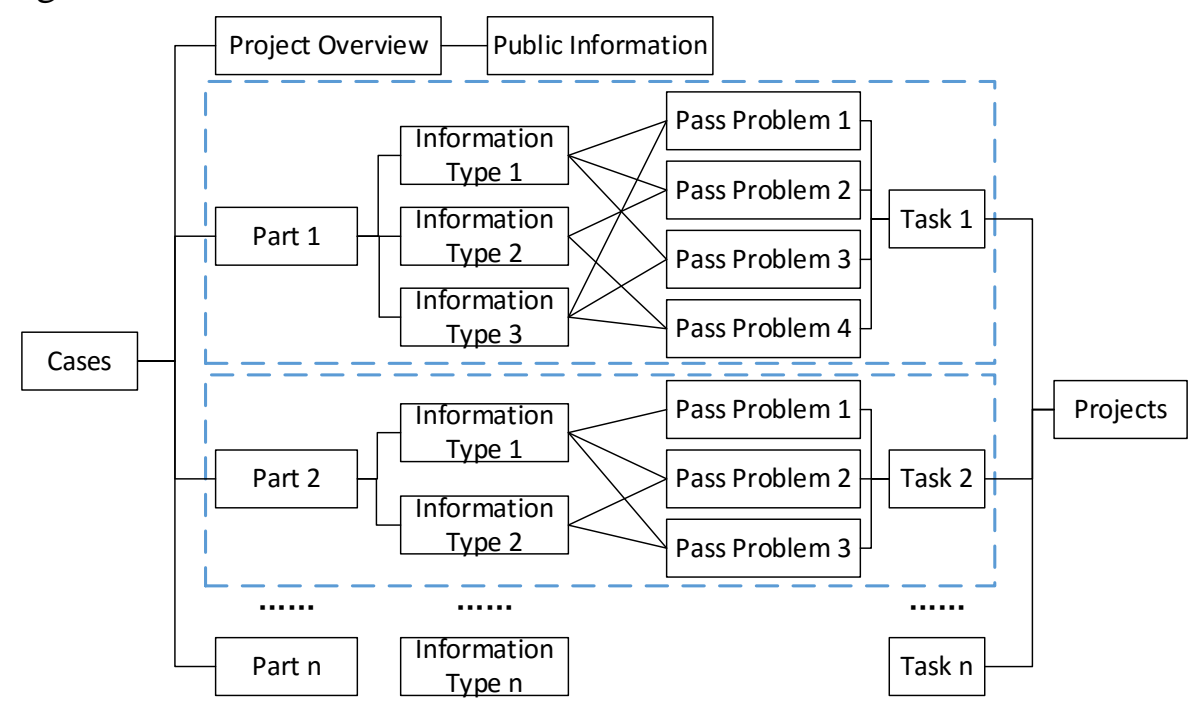

Figure 1 The Correspondence between Pass Problems, Cases and Projects

Designing cases based on the pass problem is to divide the cases secondly according to the differences of type of information required for solving pass problems after the initial division of cases in accordance with tasks. In other words, building a case of a project need to divide cases into several parts according to the different tasks, as shown in Figure 1.

\section{The Classification of the Pass Problem in the Studio Practice Teaching}

The pass problems are regarded as the core of the studio practice teaching, the design quality of which decide the teaching effectiveness. According to the ability level of each task in the project in the syllabus, the pass problems can be divided into leading questions, analyzing problems and opening questions, specific circumstances can be classified as shown in Table 1 .

Table 1 The Classification of the Pass Problem in the Studio Practice Teaching 


\begin{tabular}{|c|c|c|c|}
\hline Type & Explanation & Design requirements & $\begin{array}{l}\text { Reaching ability level } \\
\text { after completion of pass } \\
\text { problem } \\
\end{array}$ \\
\hline $\begin{array}{l}\text { Leading } \\
\text { questions }\end{array}$ & $\begin{array}{l}\text { Brought into } \\
\text { the context }\end{array}$ & $\begin{array}{l}\text { Problems set in the difficult task to ensure that the } \\
\text { difficulty of the task is among the recent } \\
\text { developments area and students could complete the } \\
\text { task through some diligences. }\end{array}$ & Understand and master \\
\hline \multirow{2}{*}{$\begin{array}{l}\text { Analyzing } \\
\text { questions }\end{array}$} & $\begin{array}{l}\text { Comparative } \\
\text { analysis }\end{array}$ & $\begin{array}{l}\text { Linking the confusing concepts in the bidding } \\
\text { practice together, let students better understand the } \\
\text { concept through comparative analysis. }\end{array}$ & \multirow{2}{*}{$\begin{array}{c}\text { Can be applied in } \\
\text { practice }\end{array}$} \\
\hline & $\begin{array}{l}\text { Cause } \\
\text { analysis }\end{array}$ & $\begin{array}{l}\text { For the core issue which must be mastered in the } \\
\text { bidding, guide students analyze problems in depth } \\
\text { principle layer. }\end{array}$ & \\
\hline \multirow{2}{*}{$\begin{array}{l}\text { Opening } \\
\text { questions }\end{array}$} & $\begin{array}{l}\text { Dispute } \\
\text { handling }\end{array}$ & $\begin{array}{l}\text { Based on real cases or objective law, construct a } \\
\text { common controversial events in bidding process so } \\
\text { that students complete mastery of knowledge in the } \\
\text { process of resolving the dispute. }\end{array}$ & \multirow{2}{*}{$\begin{array}{l}\text { Can give advice on } \\
\text { issues related to } \\
\text { professional }\end{array}$} \\
\hline & $\begin{array}{l}\text { Putting } \\
\text { forward a } \\
\text { proposal }\end{array}$ & $\begin{array}{l}\text { For the key and difficult in the bidding, set some } \\
\text { difficult problems to enhance the students' } \\
\text { comprehensive ability and ensure the students with } \\
\text { high practical ability have certain room for growth. }\end{array}$ & \\
\hline
\end{tabular}

Leading questions aim to guide students to review the relevant knowledge studying in theory courses, finally understanding and mastering knowledge. In the studio practice teaching, leading questions often manifested as the situational questions. Although the depth of them is relatively shallow, the leading questions play a directional role in the conduction of the tasks. It is not only can guide students into the appropriate context and enter the next work step smoothly, but also can inspire students to break down tasks or to identify the key and difficult in some tasks in order to ensure the successful completion of the task.

Analyzing questions are intended to develop students' ability to analyze and summarize, requiring students to apply related knowledge to practice after answering the corresponding question. Such questions need students to compare, analysis and demonstrate according to the facts. Because of its strong facticity, such questions are always solved in accordance with a fixed reflection structure and often lead to a desired result or answer. In the biding and contract management studio teaching, analyzing questions are mainly reflected in the two aspects of comparative analysis and cause analysis.

Opening questions are designed to develop students' creative thinking, and students can give some suggestions in the field of relevant issues. Solving such questions are based on individuals own knowledges, experiences and wisdom skills, stressing individuals cognitive strategies and personal style. Moreover, such questions pursue personalization and autonomy and demand students to think creatively, rebuilding students' thinking patterns by using a variety of information and extending or changing the view, plot, structure in each cases. Because of the nature of work of the professional consulting, opening questions mainly reflect by two aspects of disputing resolutions and proposing programs in the biding and contract management studio teaching.

\section{The Design Method of the Pass Problem in the Studio Practice Teaching}


Each projects don't corresponds to all types of questions in the studio practice teaching. However, the questions are selected according to the actual course content in order to improve students' the level of thinking and the way of practice. In the following, taking the biding and contract management studio as an example, expound the specific design method of the pass problem in each task.

Select the type of questions according to the complexity of the task. In some complex tasks, one or two introductory questions are needed to help students to enter the situation of studio teaching. For example, if the task named "the compilation of the bid evaluation method" is complex in the project named "the compilation of the bidding documents", and students haven't been contacting the standard format or file about the bid evaluation method in the prior courses, teachers can put forward the leading questions like "What king of context can reference the standard format and what king of context need to be adjusted when we draw up a specific project" to guide students to discover that the key to the compilation of the bid evaluation method is combining standard format and the information of the project itself.

As a practical teaching, the studio practice teaching requires students to have certain ability to analyze and solve practical problems after learning studio courses. Therefore, the biggest proportion of pass problems should be the analyzing questions. For the difficulties and fallibilities in cases or objective laws, designing the questions of comparative analysis and cause analysis can improve students' understanding and mastering to those points. For example, in the task called "the compilation of the bid evaluation method". In order to let students understand the differences between the prequalification and the post qualification, teachers can describe the relevant project information in the case and design pass problems like "Try to analyze and choose the suitable qualification method to this project according to the project background and requirements in the case." Students need to understand not only differences and similarities but also the applicability between the prequalification and the post qualification. Besides, students could apply these application conditions to analyze the qualification method of a certain project. Finally, attain the capacity requirements to solve practical problems.

At the end of each task, teachers can decide whether design opening questions or not to improve students' comprehensive ability based on the corresponding ability hierarchy. In those task with larger difficulties, teachers can design some opening questions. For instance, in the project called "the compilation of construction claim reports", the task of collection and analysis of construction claim reports is the difficulty in practical work. Teachers can design opening questions like "analyze whether the event is the experienced contractors can expect or not " to expand students' knowledge, at the same time training the students' sensitivities to the points of dissension and contention to the engineering practice, enhancing the students' comprehensive thinking abilities to solve practical problems.

Each type of pass problems should be closely integrated with the case. If teachers design pass problems based on each knowledge point in theoretical courses, students will take memorizing knowledge as a problem-solving goals in the studio practice teaching. If so, students' practical ability can not be achieved because of emphasizing knowledge acquisition too much. The studio practice teaching emphasize students apply knowledges to solve practical problems exist in cases. Therefore, only the pass problems are closely integrated with the cases, can it help students to obtain the corresponding practical skills.

Table 2 Design Examples of Pass Problems in the Studio Practice Teaching 


\begin{tabular}{|c|c|c|c|}
\hline & & Based on the knowledge points & Based on the cases \\
\hline $\begin{array}{l}\text { Leading } \\
\text { questions }\end{array}$ & $\begin{array}{l}\text { Brought into } \\
\text { the context }\end{array}$ & $\begin{array}{l}\text { Learning the compilation format of } \\
\text { bid evaluation method in the } \\
\text { "standard construction bidding } \\
\text { document", discuss what kind of } \\
\text { context can learn from these } \\
\text { standard versions and what kind of } \\
\text { context need to adjust by } \\
\text { combining the characteristics of } \\
\text { the project }\end{array}$ & $\begin{array}{l}\text { Learning the compilation format of bid } \\
\text { evaluation method in the " standard } \\
\text { construction bidding document", } \\
\text { combining characteristics of the project in } \\
\text { the case, discuss what kind of context can } \\
\text { learn from these standard versions and } \\
\text { what kind of context need to adjust by } \\
\text { combining the characteristics of the } \\
\text { project? And show how to adjust } \\
\text { combining with the case. }\end{array}$ \\
\hline \multirow[b]{2}{*}{$\begin{array}{c}\text { Analyzing } \\
\text { questions }\end{array}$} & $\begin{array}{c}\text { Comparative } \\
\text { analysis }\end{array}$ & $\begin{array}{l}\text { What are the differences between } \\
\text { the prequalification and the post } \\
\text { qualification? }\end{array}$ & $\begin{array}{l}\text { According to the background and } \\
\text { requirements of the project in the case, try } \\
\text { to analysis what kind of method are } \\
\text { suitable for the project, the prequalification } \\
\text { or the post qualification? }\end{array}$ \\
\hline & Cause analysis & $\begin{array}{l}\text { Try to analysis the common } \\
\text { dispute reasons when the employer } \\
\text { and the contractor determine the } \\
\text { variation price }\end{array}$ & $\begin{array}{l}\text { In event } 3 \text {, in order not to affect the } \\
\text { progress, employer ordered the contractor } \\
\text { implement the variation immediately after } \\
\text { receiving the variation instruction, while } \\
\text { the variation price still not determine. } \\
\text { Thus, the two sides dispute to the } \\
\text { determination of variation price after the } \\
\text { end of the variation. Analysis the "standard } \\
\text { construction bidding document" find the } \\
\text { root causes of this phenomenon, compare } \\
\text { the agreement of the situation in foreign } \\
\text { contracts such as the FIDIC(1999) and the } \\
\text { AIA(2004), and present own views and } \\
\text { suggestions. }\end{array}$ \\
\hline \multirow[t]{2}{*}{$\begin{array}{l}\text { Opening } \\
\text { questions }\end{array}$} & $\begin{array}{l}\text { Dispute } \\
\text { handling }\end{array}$ & $\begin{array}{l}\text { In which case, the lack of the } \\
\text { preliminaries in the BQ for } \\
\text { tendering can be identified as the } \\
\text { missing items of the BQ for } \\
\text { tendering? }\end{array}$ & $\begin{array}{l}\text { Whether the preliminaries should be } \\
\text { adjusted when it has some missing items or } \\
\text { not often causes dispute to both sides of } \\
\text { the employer and contractor. Analyze } \\
\text { whether the missing items of preliminaries } \\
\text { can adjust in event } 2 \text {. Further discuss under } \\
\text { what circumstances that contractors can } \\
\text { request defining preliminaries not listed in } \\
\text { the BQ for tendering as missing items? }\end{array}$ \\
\hline & $\begin{array}{c}\text { Putting forward } \\
\text { a proposal }\end{array}$ & $\begin{array}{l}\text { In practice, how to understand } \\
\text { concept of "experienced } \\
\text { contractor"? }\end{array}$ & $\begin{array}{l}\text { According to the case background and the } \\
\text { event, illustrate whether the event is an } \\
\text { experienced contractor can anticipate or } \\
\text { not. And explain the reasons. }\end{array}$ \\
\hline
\end{tabular}


As shown in Table 2, each type of problem is divided into knowledge-based design and case-based design. The main different is that students only needs to understand or acquire the appropriate knowledge when solve the knowledge-based questions. While the case-based questions contact the engineering practice, students' knowing the appropriate knowledge is just the first step in solving the pass problems. Also, students need to combine the knowledge with the information provided by the cases and use their own logical thinking to output the final problems result. Accordingly, in the problem-solving process, we can not only concern about memorizing and applying knowledge, but also stressed the importance of thinking skills upgrading. In the design of questions of some dispute resolution and program proposing, it should also be noted that level of problems need to rise from the special nature to the universal one. For example, the final problem can present the one like "Under normal circumstances, how to deal with these problems?". Let students summarize the method of handling problem in cases and generalize the treatment methods of such problems under normal circumstances.

\section{Conclusion}

Engineering management specialty has much practicality. Professional knowledge system also focus on the understanding and solving problems. Problem orientation conform human cognitive rules and thinking laws. Thus, the studio practice teaching needs to insist on problem orientation. It was more conducive to understand the problem fundamentally and apply knowledge to solve problems synthetically. Simultaneously, stimulate students' awareness of problems and enthusiasm to active learning.

\section{References}

[1]Wenlian Wei, Study on the Teachers' Practical Ability in Application-oriented Universities, Global Education, 5(2014)43-52

[2]Lin Hong, Wei Xiong and Aidong Sun, Constitution Construction of Regional Application-oriented Institutions: Based on the Analysis of Modernity Domain, China Higher Education Research, 1(2012)65-69

[3]Xiaoming Fang, Jianchao Yu, Construction of Practical Teaching System for Innovative Talents, China Higher Education,5(2015)53-55

[4]Ling Yan, Yajuan Zhang, Resarch on the Construction of Competence Standards Under the Double Certificate Accreditation Mode, Science \& Technology, 23(2013)120-125

[5]Ling Yan, Shuangshuang Huo, Jiaojiao Deng, Research on Studio Practice Teaching Based on Competence Standards - Taking the Engineering Cost Major of Tianjin University of Technology as an Example, Modern Educational Technology, 6(2014)113-121

[6]Lu Feng, Yilan Kang, Zhiyong Wang etc, Reform and Practice of Problem-Learning Based Research-Style Teaching, Research in Higher Education of Engineering, 4(2013)176-180

[7]Xiaoyang Yang, Aiqun Zhang, Jiliang Shen, From Idea to Behavior, The Survey and Thought on the Outlook of Questioning and the Teaching Behavior with Questions in Teaching, Curriculum, Teaching Material and Method,10(2005)34-39

[8]Ming Li, Weihe Zhong, A Guide for Conducting Translation Workshop, Chinese Translators Journal, 4(2010) 32-36+95

[9]Feng Wang, Zheng Wang, Competency-Based Translation Teaching Exemplified by Translation Workshop Approach, Modern Educational Technology,4(2013)76-80

[10]Yue Huang, University Teachers' Roles on Workshop Model, University Education Science,6(2011)56-60 
[11]Ling Yan, Lijuan Zhu, Jiaojiao Deng, Research on the Competence Cultivation Mode of Engineering Management of the Biding and Contract Management Workshop, Science \& Technology Progress and Policy,11(2014)131-137 